\title{
Employment in the Nigerian Agricultural Labour Market: Barriers and Forecast
}

\author{
John C. Odozi*Ikhimalo Odufa Patience ${ }^{\dagger}$ John Awaebe ${ }^{\ddagger}$ \\ and Marian Agbugui ${ }^{\S}$
}

October, 2018

Acknowledgement This article is a revised edition of the paper submitted for discussion toward a Blue print on Nigeria's prosperity in 2050 organized by the Management of Edo University Iyamho, Edo State. We appreciate management for stimulating interest in the important area of research. Also appreciate all comments and contribution made on the paper during the round table discussion.

\begin{abstract}
Although the Agricultural sector is an important source of employment in Nigeria, it has been experiencing a rapid decline in employment share since 2001 . While economic theory predicts a decline in agricultural labour in the course of a country's development. The challenge of high unemployment rate in rural areas and the low capacity utilization in the manufacturing sector raise critical concerns about among academics and policy makers. Namely, the pressing challenge of raising agricultural productivity and commercialisation to boost employment uptake. Against this background, the study reviewed the demand and supply side barriers in the agricultural labour market. Also forecasted employment as well as suggested policies for a more efficient agricultural labour market.
\end{abstract}

\footnotetext{
*chiwuzulum@yahoo.com, Department of Economics, Edo University Iyamho, Edo State, Nigeria

${ }^{\dagger}$ Department of Plant Biotechnology, Edo University Iyamho

${ }^{\ddagger}$ Edo University Iyamho

$\S$ Department of Biotechnology, Edo University Iyamho
} 


\section{Introduction}

Although agricultural employment share remains substantial at 48.19 percent (National Bureau of Statistics report for the third quarter of 2017), there is a declining trend since 2001. In the rural sector where agricultural activities predominate, there is high unemployment rate estimated at $25.6 \%$ (NBS, 2011). While the evidence for Nigeria is consistent with economic theory that predicts a declining agricultural employment share as development progresses, the double challenge of high rural unemployment and manufacturing low capacity utilization suggests a distorted structural change. Thus the pressing challenge of how to commercialize the sector and raise agricultural productivity to boost employment uptake. Agricultural growth is necessary to create employment opportunities but not sufficient as the employment absorption capacity of growth is also critical. Unfortunately the absorption capacity of the sector is considered to be low (Ajaikaye et al.,(2016).In the last one and half decade agricultural contribution to GDP declined sharply "from 42.66 per cent in 2000 to 40.84 per cent in 2010" (Olomola, 2007). It declined further to $28.44 \%$ in the third quarter of 2017 , although an incremental leap compared to the contribution over the period $2010-2014$ estimated at 21.9 percent. Agricultural growth on the other hand, declined by $1.47 \%$ when compared with the 2016 growth estimate at 4.50 percent in the third quarter of 2017 (NBS, 2017).

Understanding the demand and supply side barriers in the agricultural labour market is insightful for understanding the employment crisis in the sector as well as for employment needs forecasting. Employment forecasting is an important area that has not been explored in Nigeria particularly for the agricultural sector. This becomes even more important for manpower planning given the working-age bulge envisaged by many social scientists for Nigeria (Bloom et al., (2010) Fox et al,(2013). Employment "forecasting in a systematic fashion began in the United States when a large number of soldiers came back from World War II and the government was concerned about where these people could find jobs" (Neugart and Klaus 2002). Fox et al.,(2013) argues that despite the political, social and economic importance of employment forecast, the data needed for such exercise is often not collected regularly or readily made available to the public in most countries in Sub-Saharan Africa making it hard to assess the prospects for employment creation in the future. 


\subsection{Nature of Labour supply and Barriers in the agri- cultural sector}

The Agricultural sector can best be viewed as a continuum of upstream and downstream activities whether in the sub-sector of crop, livestock, forestry or fisheries. Primary agricultural production activities whether planting/rearing, weeding/nurturing and harvesting constitute the upstream economic activities from which primary commodities emerge. Following these are postharvest or secondary activities that constitute downstream activities. The secondary activities add value to the primary product, improving its quality and rendering it less perishable. Key downstream commodity activities include: storage, processing into intermediate or final (finished) products, and marketing/distribution through domestic and/or export trade (Manyong et al., 2003).

In the agricultural sector, labour supply comes basically from rural population/small holder farmers and their families. Over the years, Nigeria institutions of higher learning with Faculties/Departments of Agriculture have increased also in the number of graduates trained in agriculture and related disciplines thus creating a pool of skilled labour for the agriculture industry" ( Nuga and Asimiea, 2015). Labour supply in the agricultural sector faces a number of barriers. The ecological constraint in agriculture means that "agricultural commodities normally do not require the same amount of continuous labour input over the whole year. In other words, the predominating rain fed system of agriculture and one harvest per year production limit the number of labour hours allocated. Institutional constraint also limits labour participation in the agricultural sector. The existence of distorted factor price above the market-clearing price often causes labour outmigration from agriculture to other sectors. Such outmigration arises because of the uncompetitive nature of the agricultural sector. The out-migration of the youth and more skilled people to seek better employment opportunities in urban areas also raises the challenge of an ageing population in Nigeria's rural agriculture. There is also the barrier of imperfect information that raises the cost of job search and uncertainty. These dynamics have effect on labour supply and employment levels. There are market failures that constrain small farmers in terms of other factors of production such as land, capital, financial assets and public infrastructure. Such rigidities and imperfections in the labour market imply that labour is not fully employed (Tocco et al., 2012). Other factors include urban bias in provision of social services (Ogundele, 2006). 


\subsection{Nature of labour demand and Barriers}

The National Bureau of Statistics categorizes employment in the agricultural sector as (1) paid employment (2) self-employment in farming, (3) selfemployment in non-farming, (4) Paid apprentice and (5) unpaid household worker. Jobs can be permanent, temporary/causal, fixed term, etc. (NISER, 2015). In rural agricultural there are various economic activities grouped as crop, livestock, forestry/hunting and fisheries upon which labour is demanded or utilized. Within this broad groups are various employment areas where skilled and unskilled workers can be employed. Examples of employment areas are (1) extension agencies (2) Research and Academic (3) seed production companies (4) fertilizer industry (5) pesticide industry (6) Banking and Insurance (7) Agro-processing (8) Agri-marketing (9) farms (10) others. However in the recent establishment survey carried out by the National Bureau of Statistics, these areas are not explicitly defined limiting explicit forecasting of employment. However, small farms are the predominating employers of labour constituting 79 percent of employment. This translates to Forty two million (42.95) small farms as at 2009. Of this amount, crop farms constitute $40 \%$, Livestock (30\%), poultry (26\%) and fish $(4 \%)(\mathrm{NBS} / \mathrm{CBN}$, CCC, 2012).

Table 1: Number of Small farms in Nigeria

\begin{tabular}{|l|r|r|r|r|}
\hline ACTIVITY & $\mathbf{2 0 0 6}$ & $\mathbf{2 0 0 7}$ & $\mathbf{2 0 0 8}$ & $\mathbf{2 0 0 9}$ \\
\hline Livestock(Millions) & 12.94 & 12.42 & 14.29 & 12.67 \\
Poultry(Millions) & 9.63 & 11.31 & 10.95 & 11.38 \\
Crop(Millions) & 15.52 & 15.73 & 15.1 & 17.03 \\
Fish(Millions) & 1.7 & 1.73 & 1.75 & 1.87 \\
\hline Total(Millions) & 39.78 & 41.2 & 42.09 & 42.95 \\
\hline
\end{tabular}

The relationship between output growth and employment has been widely studied based on what is known as Okun's law. The law postulates an inverse relationship between growth of output and the rate of unemployment. The rate of agricultural growth therefore becomes an important determinant of labour demand. Keynesian economists advocate increases in government and private investment or by government policies that indirectly encourage investment in the sector. In rural agriculture, public (Government) investment is far below the 10 percent budgetary allocation stipulated in the 2003 Maputo declaration by African Leaders. Until 2007 the country budgeted less than 3 per cent of its annual budget on Agriculture with only a little increase to 5 per cent per annum in recent times(Olomola, 2013). Cooperate Private sector investment is lagging behind. Out of about 150 companies quoted on 
the Nigeria Stock Exchange (NSE), in August 2005, only five were primary agricultural companies. Foreign investment has not fared much better. Agriculture's share of the total amount of foreign investment declined from about 2 per cent in 1981-85 to less than 1 per cent in the 1996-2000 period (Eboh, 2005). Poor investment increases uncertainty and restricts labour demand. Others factors affecting investment are policy, institutional, environmental, external, land tenure, and agricultural labor market and wage. Also good trade policies, sound macroeconomic policies, well-functioning financial markets, good relations with neighboring countries, and civil conflict (Bloom et al., 2010).

\subsection{Employment forecast}

There are various approaches used for forecasting employment. Ramarao et al.,(2013) identified the following manpower forecasting approaches namely(1)Employer survey methods, (2) Norm-based methods (3) Time-series and regression (linear/non-linear, simple/multiple) models (4) Mathematical models (5) Rate of returns approach (6) Parnes's manpower requirements approach. This paper however used an ad-hoc employment forecasting approach to project total employment and jobs to be added between 2017 baseline and 2050. Also generated a breakdown of the project employment by educational levels and employment categorization namely: (1) paid employment (2) self-employment in farming, (3) self-employment in non-farming, (4) Paid apprentice and (5) unpaid household worker. We used economic parameters derived in Alemu (2015), Ajakaiye (2016) and Bloom et al.,(2010). We used employment growth rate of $2.5 \%$ built on $0.6 \%$ growth employment elasticity and agricultural growth rate of $5 \%$. The working age population with at least one hour of work per week estimate for 2017 from the National Bureau of Statistics was used as the base estimate. On this basis, employment is expected to grow in rural agriculture from $28,774,076$ in 2017 to $79,456,846$ in 2050 given a step wise reduction in unemployment from the current $23 \%$ to $5 \%$ in 2050. Jobs to be added will increase from 1,898,342 in 2018 to $11,889,437$ by 2050 . Of this number, $79 \%$ is self-employment in farming, $3 \%$ in self-employment in non-farming, $7 \%$ paid wage employment, $1 \%$ paid apprentice and $10 \%$ unpaid household worker. In terms of educational qualification, those with Post-secondary qualification constitute $8 \%$, secondary school qualification 26 percent, Primary school qualification, 46 percent and no education $45 \%$

The projection reveals that the number of needed in agriculture would to continue to grow. This projection has important implications for employment policies. Governments need to undertake the measures required to 
attract self-employed enterprises that provide wage employment for lots of people. In this regard, agricultural policies must focus on increasing public and private investments Investment in physical capital such as dams, irrigation structures, grain silos, farm machinery and rural roads. Social capital such as human capital through education and health, and on-the-job training and extension services. Institutional capital through investments in organizations and the regulatory environment. This would enhance the productivity in agriculture and thereby making it attractive for the younger generation. Also to increase the number of paid jobs by encouraging an enabling investment climate for agribusiness corporate organizations.

\subsection{Conclusion}

Traditionally, the Agricultural sector has been an important source of employment. But the agricultural employment share has been declining rapidly since 2001. More still, is the paradox of high unemployment rate in rural agriculture. On the supply side, a number of barriers were identified while on the demand side, low investment was critical. From our ad-hoc projection, employment is expected to grow from 28,774,076 in 2017 to $79,456,846$ in 2050. Jobs to be added will increase from 1,898,342 in 2018 to 11,889,437 by 2050 . Of this number, $79 \%$ is self-employment in farming, $3 \%$ in selfemployment in non-farming, $7 \%$ paid wage employment, $1 \%$ paid apprentice and $10 \%$ unpaid household worker. In terms of educational qualification and skill, those with Post-secondary qualification constitute 8\%, secondary school qualification 26 percent, Primary school qualification, 46 percent and no education $45 \%$. On the demand and supply side, agricultural policies must focus on increasing public and private investments Investment in physical capital such as dams, irrigation structures, grain silos, farm machinery and rural roads. Social capital such as human capital through education and health, and on-the-job training and extension services. Institutional capital through investments in organizations and the regulatory environment. Expenditure on education should target at upgrading managerial and employability skills, with the purpose of improving factor mobility and thus toward a more efficient allocation of labour. Investments in infrastructure are crucial for improving rural markets and for strengthening rural-urban linkages, hence facilitating market access and creating better employment opportunities. A further focus point consists in supporting agricultural extension as well as small business development, reducing capital constraints and providing access to credit, markets, technical information and assistance. Adequate transport and communications are necessary in rural areas in order to stimulate productivity, provide linkages with the wider economy and thus 
lead to improved and more efficient labour outcomes.

\section{References}

[1] AJAKAIYE , O., JEROME, A.T., JEROME , D.X and ALABA,O.A.(2016).Understanding the relationship between growth and employment in Nigeria. understanding the african lions- growth traps and oppurtunities in six dominant african eeconomies. $32 \mathrm{p}$

[2] Alemu. Z.G. (2015).The Challenge of Job Creation in Nigeria.(2015). Africa Economic Brief .6(8):16p

[3] Bloom, D., J. Finlay, S. Humair, A. Mason, O Olaniyan, and A. Soyibo (2010). 'Prospects for Economic Growth in Nigeria: A Demographic Perspective'. Paper presented at the IUSSP Seminar on Demographics and Macroeconomic Performance held at Novotel, Gare de Lyon, Paris, France 4-5 June 2010. Available at: http://www.ntaccounts.org/doc/repository/BFHMOS2010.pdf (accessed on 24 October 2015).

[4] Eboh, E. (2005) 'Models of Private Sector Investments in Agriculture: Towards Appropriate Policy and Legislative Framework'. Policy Brief Series 2, No 1, Legislative and Policy Agenda for Nigerian Agriculture. Enugu: AIAE.

[5] Fox Louise, Haines Cleary, Muñoz Jorge Huerta, and Thomas Alun (2013) Africa's Got Work to Do: Employment Prospects in the New Century IMF Working Paper African Department WP/13/201

[6] Manyong, V. M., A. Ikpi, J. K. Olayemi, S. A. Yusuf, R. Omonona, and F. S. Idachaba. 2003. Agriculture in Nigeria: Identifying Opportunities for Increased Commercialization and Investment. Main Report, International Institute of Tropical Agriculture (IITA), USAID/NIGERIA, and University of Ibadan.

[7] NBS/CBN, CCC, 2012 National Bureau of Statistics/Central Bank of Nigeria/Nigerian Communications Commission (2009). Annual collaborative Survey of Social Economic Activities in Nigeria. Report.

[8] Neugart, Michael; Schömann, Klaus(2002) Employment outlooks: Why forecast the labour market and for whom? WZB Discussion Paper, No. FS I 02-206 
[9] Nigerian Institute of Social and Economic Research NISER (2015) Youth Employment and Job Creation in Nigeria: Context and Sectoral Trends. NISER Publication

[10] Nuga, B.O. Asimiea, A. O. (2015). SWOT Analysis of the Nigeria Agricultural Sector. IOSR Journal of Agriculture and Veterinary Science (IOSR-JAVS) Vol. 8, Issue 4 Ver II. PP 51-53

[11] Ogundele, (2006). Agricultural Labour Outmigration and Food Security in Nigeria: An Empirical Analysis. NISER Monograph series No. 11

[12] Olomola, A. S. (2013).Policy options for agricultural investments and Governance of markets In support of small-scale agriculture inNigeria. Oxfam Research Reports. 42p

[13] D. Ramarao, Rashmi Agrawal, B.V.L.N. Rao, S.K. Nanda Girish P. Joshi (2014) Agri-Manpower Forecasting and Educational Planning, The Journal of Agricultural Education and Extension, 20:4, 397-412, DOI: 10.1080/1389224X.2013.846869

[14] Tocco Barbara, Davidova Sophia, and Bailey Alastair (2012)Supply and Demand Side Limitations Affecting the Structure of Agriculture and the Rural Economyhttp://aei.pitt.edu/58524/1/Factor_Markets_21.pdf

[15] World Bank, 2018. World Development Indicators, on-line version, Washington, DC. 


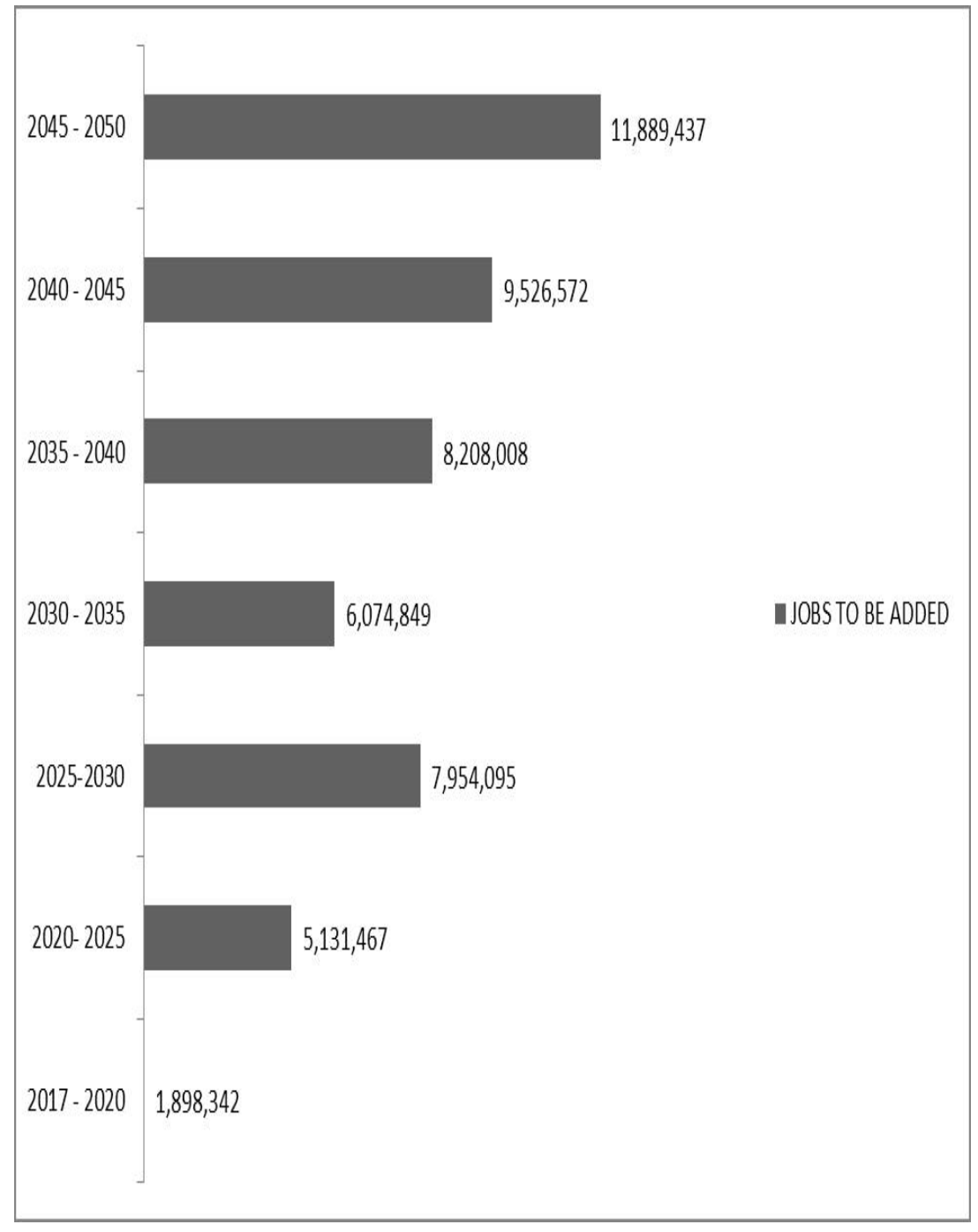

Figure 1: Number of jobs to be added 


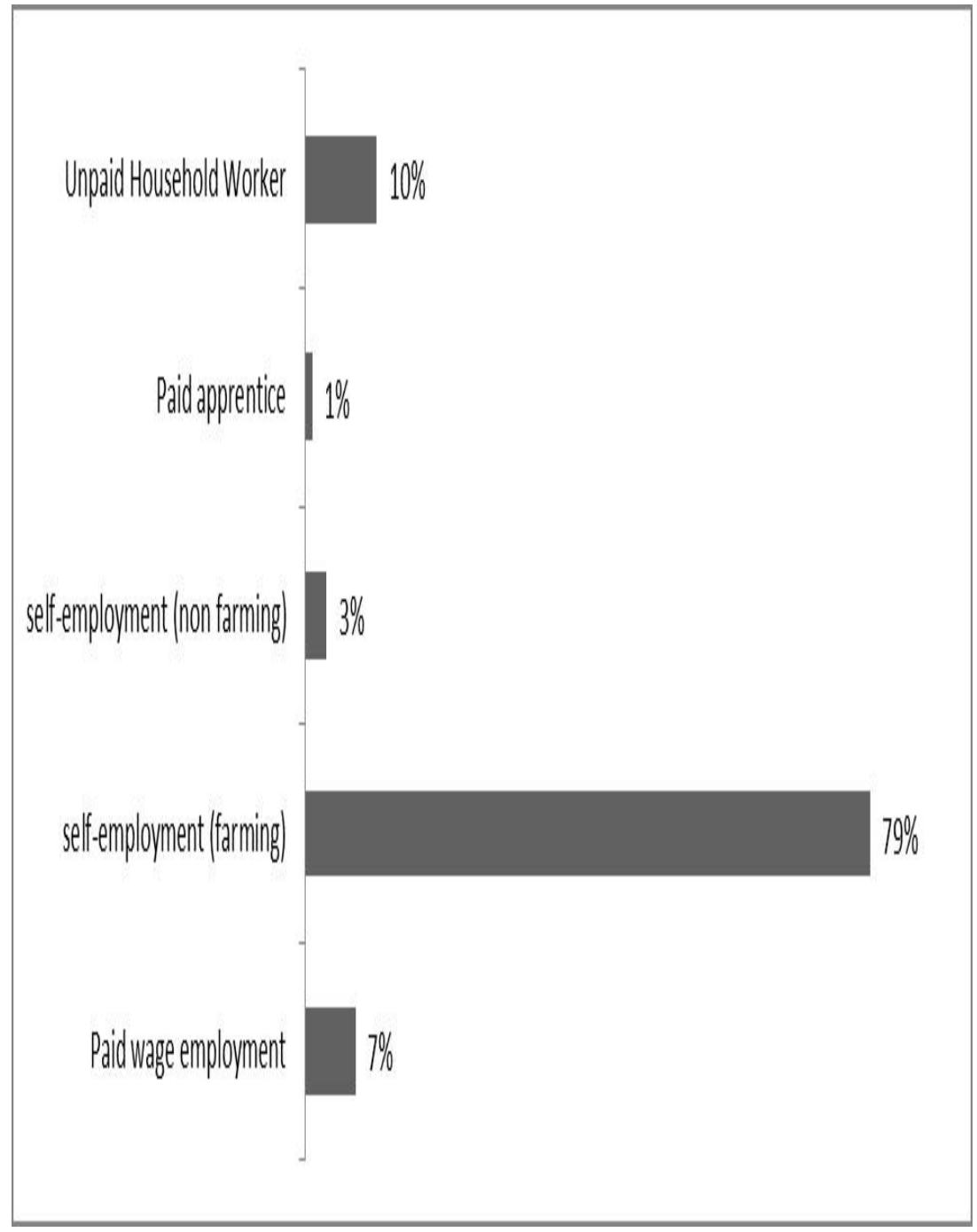

Figure 2: Number of jobs needed by employment type 


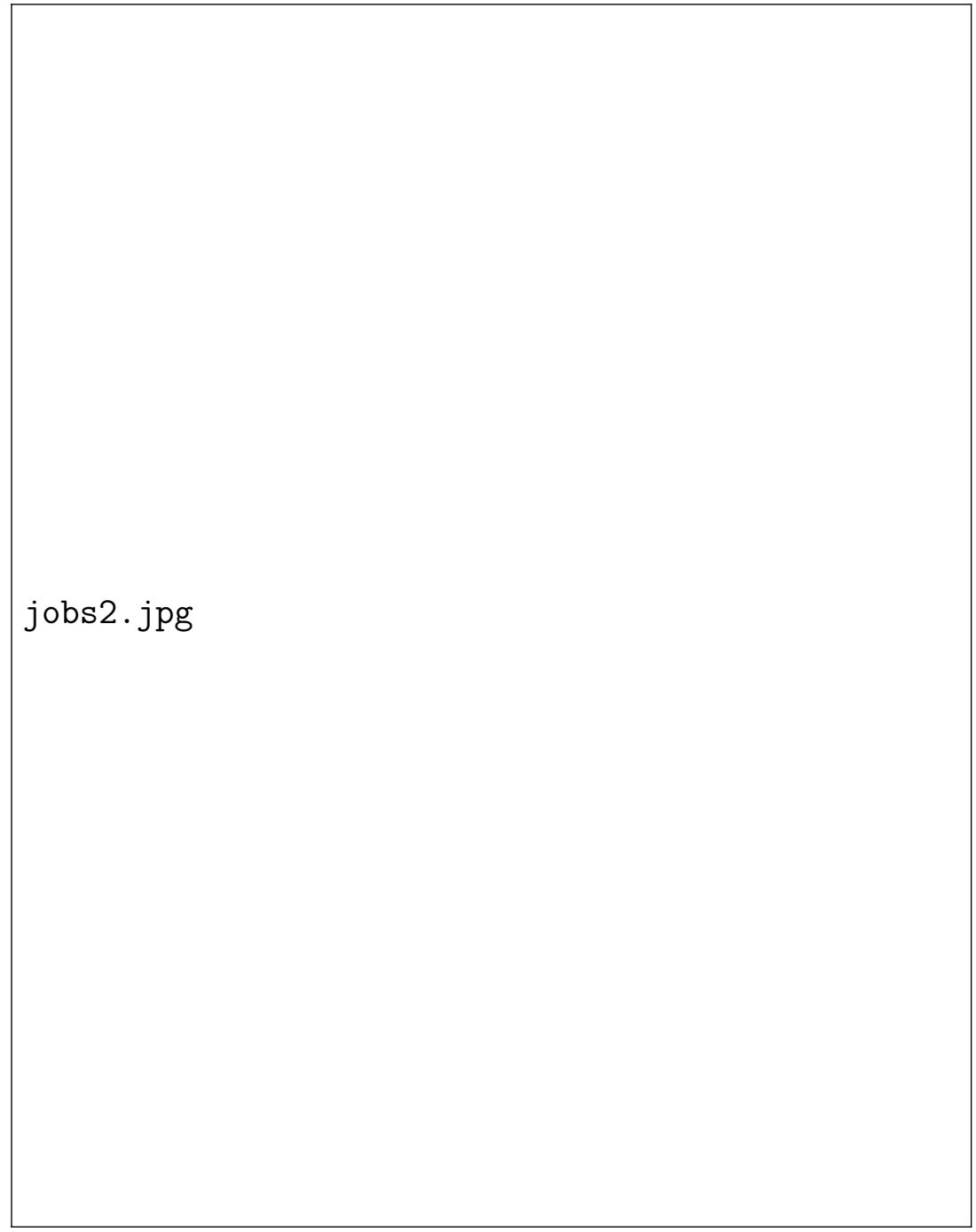

Figure 3: Number of jobs needed by educational attainment 